\title{
Carolingian History and the Historians' Metanarrative
}

\section{Dmitri Starostin}

\section{ABSTRACT}

The essence of historian's craft or his or her ability to construct narratives where only bits of information had reached him or her by way of written or oral tradition is one of the main problems of investigation in the discipline of history. Historians of the Carolingian age present a particularly difficult task for researchers because their work joined in one narrative both their own attitudes and judgments and the attempts to construct a pro-Carolingian, universal and thus non-partisan historical outlook. Looking to the past, Carolingian historians balanced on the verge between providing a contemporary account of recent events, the narrative being shaped in favor of ruling kings, their patrons, and the need to look deeper into the past in search of forces that underlay the Carolingian success. The historical picture we use today was constructed by contemporary historians and it could not have been produced by relying only on documents. It was not a "fabrication" in the negative sense of the term, but a "construction" in the positive meaning. Thus, key episodes of Charlemagne's reign could not be understood without the Carolingian historians' "authorial license". Only the historical narrative construed a meaningful sequence of events that could be reproduced in memory. But at the same time, once we approach these key events, we are left with historians' interpretations rather than facts. Thus, the Carolingian period in the history of the Frankish kingdom, and particularly the reign of Charlemagne, can be seen as a constructed narrative, which cannot be perceived without looking at the context of its origin and the authors' "creative" influence on the representation of the past.

\section{KEYWORDS}

Constructivism, Contingency, Historical culture 
The essence of historian's craft or his or her ability to construct narratives where only bits of information had reached him or her by way of written or oral tradition is one of the main problems of investigation in the discipline of history. Historians of the Carolingian age present a particularly difficult task for researchers because their work joined in one narrative both their own attitudes and judgments and the attempts to construct a pro-Carolingian, universal and thus non-partisan historical outlook (NELSON 1985, p. 293; MCKITTERICK 2004, p. 85; GANZ 2005, p. 51; GANZ 2014, p. 145). Thus histories written in the Carolingian age are particularly relevant for considering the historian's craft and his ability to create the narrative which constructed the perception of an epoch. Looking to the past, Carolingian historians balanced on the verge between providing a contemporary account of recent events, the narrative being shaped in favor of ruling kings, their patrons, and the need to look deeper into the past in search of forces that underlay the Carolingian success. Although the history of the Carolingian Frankish kingdom does not suffer from uncertainties in the basic facts, there are certain events or periods, I argue, which have been transformed by contemporary historians into stories and narratives that delivered both historical "fact" and subjective "representation". This paper argues that if one looks at the "metanarrative" of Carolingian history, or, in the more conventional terms, the sequence of events that were considered key by the historians of that age, one may see that key events were in fact constructed by later historians in a way that helped distance the actual past and established its interpretation as a definitive replacement instead. In a sense, changing the perspective on the past was a staple of Carolingian historiography, but this paper argues that this practice does not need to be understood in negative terms as producing stories singularly aimed at deception. In fact, I argue that most of the Frankish history in this period needed a personal touch from historian for us to approach the decisionmaking process of the rulers and the reception of their will by the magnates. 


\section{The Carolingians in the Mediterranean and European contexts}

The coming of the Carolingians to power was a complex event that took place as the result of phenomena of both global and local significance. Since the publication of $\mathrm{H}$. Pirenne's Mohametet Charlemagne in 1937 scholars started thinking about the success of Pippin III and Charlemagne in the context of the contact between the Mediterranean Roman civilization, which had become Christian in the course of Late Antiquity, and the civilization of Islam, which had originated in the desert regions of Middle East (PIRENNE 1937). The context of this contact and tension between the civilizations became particularly poignant because the Islam was to a large extent a development of the Judeo-Christian religious ideals and its geographical location complemented the Mediterranean Roman Empire because it occupied the "desert Mediterranean" of the Arabian Peninsula, of the North Africa and of the similar regions in the Middle East. Historical and archaeological studies show that key cities of the Muslims, Mecca, Medina and some other were located in the near vicinity of the trade routes to the Mediterranean and yet far enough from the span of the Roman and later Byzantine legions, and thus the expansion of Islam in the desert areas close to the Mediterranean was similar to the earlier expansion of Rome throughout the Mediterranean. The danger of Islam's spread to the Mediterranean civilization and hence to the Frankish kingdom was in its leaders' masterful ability to use the Roman trade routes, although initially the Muslims were limited to traffic by land. Considering their superlative ability of quick transportation in the desert by horseback, the Arabs and the peoples they had recruited for their expansion were a formidable contender to the Mediterranean, the Byzantine Empire and the kingdoms that had emerged on the ruins of the Western Empire. Thus, the military tactics of the Arabs, the one of quick raids on horseback, which had already been reported by Ammianus Marcellinus in the late fourth century, required creating an army in the Frankish kingdom that would be able to fight on the horseback (AMMIANUS MARCELLINUS 1999, Lib. 14, 4; BRUNNER VON SCHWERIN 1958, v. 1, 
p. 336; WHITE 1962, p. 11-13). Further investigations of the archaeology of the early Middle Ages showed that despite all problems of dating, since the eighth century the Frankish trades routes showed a steady decrease in length and the gradual disappearance by the time between the spread of Islam and of the coming of the Carolingians (HODGES WHITEHOUSE 1983, p. 20-53, 77-101).

The Iberian peninsula became a buffer zone as a result of the Muslim expansion, and thus the very foundation of the former Western Roman empire changed as the zone of stability, located in Aquitaine and maintained by Visigoths and then by the Franks, turned in fact into the zone of instability. The battle of Poitiers (732), long viewed as an important event in the history of the confrontation of the two civilizations (WATSON 1993, p. 68), and reduced in significance by modern scholars, was a sign of how far North the Muslim forces could make raids (CARDINI 2001, p. 9). The balance between the regions that had formed the dioceses of the Roman empire changed significantly with the coming of the Muslims, and especially drastic were the changes in the relationships between Gaul and Spain. Spain used to be the region that buttressed the authority of the Empire. Thus when the elites of the Eastern and the Western parts of the Empires were in disarray due to the defeat of the Roman legions at Adrianople at the hands of the Visigoths (378), it was the Spaniard Theodosius (later Emperor Theodosius I (379-395)) who was invited to employ his military prowess to restore the Roman defenses and to withstand the Gothic threat. The Goths were settled in 417 in the place that provided key communication routes between Gaul and Spain, Aquitaine. The placement of the Goths created competition between them and the Franks as the latter could claim that the treaty of 359, supported by emperor Julian the Apostate, gave them certain rights in the diocese and no doubt made them the foederati whose rulers started their careers with showing their ability to reduce Goths to their initial regions provided to them by emperor Honorius in 417 (AMMIANUS MARCELLINUS 1999, Lib. 16, cap. 3). But as in the case of Clovis and the battle 
of Poitiers, this was a manageable competition that required the Frankish kings to claim their rights in those regions of the South which the Goths could in no way claim, as in Angouleme, Clermont and some others that had not been given to the Visigoths for settlement. The coming of the Muslims destroyed the balance between the Visigothic Spain and the Frankish Gaul and put under severe pressure the border region between the two, Aquitaine. The Carolingians were the rulers who managed to address the new challenges, which the Merovingians were unable to approach due to their status as the "governors" of the Empire in Gaul. Thus while the Merovingians held true to their role as those who kept the imperial decorum in Gaul, their mayors like Charles Martell started to break some unwritten rules of the Frankish kingdom, which it possessed as the heir to the former Roman province, by consolidating in their hands the military power that befitted rather the imperial commanders of the fourth and fifth centuries and that was not considered as belonging to the Merovingian Frankish kings. Thus the early history of the Carolingians starts with the same feats of valor as did the history of the Merovingians: the conquest of Aquitaine, which was considered to be lost because the removal of the Merovingians broke what could be considered as a dynastic alliance rather than a territorial annexation. The war in Aquitaine was the first one by which Pippin III supported his legitimacy as an heir to his father Charles Martell and the beginning of the military successes of Charlemagne who definitively secured Aquitaine for himself from the Vasconian dukes (EINHARD 1911, cap. 2, 5). This aspect of the Carolingian rule deserves a special mention because it was their peculiarity of the rulers who restored the unity of the North and South of Gaul that had been created by Clovis and other Merovingians of the first two generations and who did so in the context of contact with another, much less known civilization of Islam. But interestingly, despite this success of restoring the balance in the South of France, in Aquitaine, it took a long time for the Frankish kings of the second dynasty to get the treatment from the historians they deserved as the successful rulers. 
The subjectivity which ruled the coverage of the Carolingians' history started with the lack of an adequate treatment of their successes in Aquitaine and extended to many events of their rule. The Carolingian period got its own peculiar assessment from every historical school that had emerged in the Modern period, and only in the second half of the twentieth century the evaluations of their rule began to merge. This overview is not meant to serve as a comprehensive introduction to the historiography of Charlemagne's reign, which would be impossible within the limits of any article. But one difference in approach seems to be visible. French historians, who claimed the Carolingian heritage in the most significant way because it was the Carolingian Charles the Bald who laid the foundations for medieval Francia and modern France, and some British historians who followed in their steps, emphasized since the early modern period the importance of this dynasty in finishing the synthesis between the Mediterranean and barbarian elements (FUSTEL DE COULANGES 1907, p. 594-610; RICHÉ 1983, p. 143; BULLOUGH 1970, p. 100-105; MCKITTERICK 2008, p. 5763). German scholarship has recently started to emphasize the cultural impetus of the Carolingians as the dynasty who sought to educate its subjects in the Christian spirit despite serious elements of a barbarian culture that were present in the area of the Frankish kingdom outside what used to be Gaul in the Roman Empire (FRIED 2014, p. 309 ff.; WEINFÜRTER 2015, p. 131-136). But while scholars North of the Alps and Pyrenees emphasized the cultural break that the Carolingian rule signified, even though that was a break that was meant to instill the elements of the Mediterranean Christian culture as the basis for cultural identity, the scholars in the Mediterranean regions tended to emphasize continuity of the Mediterranean Christian culture on the Iberian peninsula and in Gaul. Paradoxically, even though the result was the same, the approach that led to this result was different. Thus the emphasis on the attachment of the Iberian peninsula's kingdoms to the traditions of the Christian Mediterranean and its close connections to the rest of the Christian West was already evident in the works of two Spanish historians of the sixteenth century, Florian de Ocampo 
(1499-1558) and Ambrosio Morales (1513-1591) (MORALES; OCAMPO 1574). The latter's rewriting of the former's works in an attempt to create a general history of Spain showed a firm belief in the history of Gaul being identical to that of the kingdoms of the Iberian peninsula and, most importantly, it proposed that the Visigothic and the Frankish kingdoms showed a remarkable resilience of friendly relationships and that they continued to develop along the same Mediterranean lines even when the Franks sought to expand their authority in the South of France. Thus although this overview cannot be expanded further due to the lack of space, one may notice how the different approaches of various schools to the problem of the Carolingian "breakthrough" produced assessments of this period that were remarkably similar.

As some of its representatives became the Merovingian kings' chief officers, the aristocratic grouping that traced its origins to Arnulf, the bishop of Metz (d. 640), managed to supplant the Merovingian kings in terms of real power by the early eighth century (HLAWITSCHKA 1966, p. 63-64; BONNELL 1866; AUBIN 1935, p. 44 ff.; HLAWITSCHKA 1962, p. 17; MCKITTERICK 2008, p. 71-74; COSTAMBEYS, INNES, MCLEAN 2011 , p. 34-65). The ability to muster forces necessary to protect the southern ranges of the Frankish kingdom were among the important factors, but their discussion among the contemporaries was subdued and suppressed. This process of the coming to power of the mayors of the palace was less of a revolution then it seemed to the scholars of the nineteenth century because the Pippinids did occupy an important place with the consensus of the last Merovingian kings (REIMITZ 2014 , p. 150). In the long run, the defeat of the Saracens at Poitiers in 732 did contribute to the Pippinids' better standing among the Frankish elites because Pippin III could cite Charles Martell's successes among his family's assets:

At the time of Childeric's deposition, Pepin, the father of King Charles, held this office of Mayor of the Palace, one might almost say, by hereditary right; for Pepin's father, Charles [Martel 71541], had received it at the hands of his father, Pepin, and filled 
it with distinction. It was this Charles that crushed the tyrants who claimed to rule the whole Frank land as their own, and that utterly routed the Saracens, when they attempted the conquest of Gaul, in two great battles - one in Aquitania, near the town of Poitiers, and the other on the River Berre, near Narbonne and compelled them to return to Spain. This honor was usually conferred by the people only upon men eminent from their illustrious birth and ample wealth (EINHARD 1905, cap. 2).

Although the real extent of the Arnulfings' interest to the recording of the past and to raising the general awareness of the importance of history is a matter of significant discussion, one may still accept as the fact that in their struggle to redefine Merovingian political networks to create new political connections, the court of the Frankish mayor and later king Pippin III needed the new ways to construct his image. The coronation and the unction by two churchmen, Boniface (ca. 675 - ca. 754) and Pope Stephen II (752-757), or just by the Roman pontiff, is the evidence of this fact (LEVILLAIN 1933, p. 294-295). This was important because unlike the Merovingian Clovis, Pippin did not have the roots of his power built upon the specific consensus that had been born in the Roman diocese of Gaul, the Gallo-Roman inhabitants of which needed the help of the limes chieftains like Clovis who could exercise authority over the barbarian warriors and Franking soldiers (from Soissons) on both side of the Roman border. This search for sources of authority might have found its expression in the cultural renovation and the emergence of the rulers' interest to history as a means to sanctioning their authority that was believed to have been undertaken by Charlemagne and those surrounding him (RICHÉ 1974, p. 70; MCKITTERICK 2004, p. 5-8, 30). Partaking in the changes in self-representation, I argue, was an important component in the dynasty's interest in men of letters and in history in particular. The Carolingians themselves, with the collaboration of many other prelates, monks, and statesmen, fused the educated representations of the past with the Carolingian political program. But one may note an interesting delay in the representation of history of the Carolingians that deserves to be investigated. It is a significant delay between 
the actual deeds of the Carolingians and their acceptance by the historians as the key events of European history. It is this delayed acceptance of the Carolingians that this paper will address. This article suggests that the image of this Frankish dynasty was dependent on the historians' construction and on the audience's acceptance, rather than on the imposition from the small circle of the rulers and their trusted advisors. It will also suggest the importance of historical narratives that were indispensable as the means of constructing the image of the past and that cannot be overlooked even if modern historians possess a significant amount of administrative documents like capitularies that allow them to make conclusions about the period.

\section{Historians and the Construction of the Narrative of Charlemagne's Rule}

The construction of historical narrative was inevitably related to the question that faced not only the rulers and their family, but also the aristocracy that supported them, that of legitimacy of the Carolingian rule. The supporters of the Pippinids sought to compensate for the inadequacies of their coming to power by distorting the historical picture and overemphasizing the problems which they sought to portray as besetting the Merovingian kings (SCHUTZ 2004, p. 19). Key pieces of Carolingian history-writing that addressed the coming of Pippin III, for example, were in disagreement over the unction of the mayor turned king, on the role of the pope in his accession and in general, and on his real standing in the uneasy waters of Frankish politics. In fact, investigation of these sources allowed scholars to talk about "the illusion of royal power" (MCKITTERICK 2000b, p. 20). In a sense, therefore, the very beginnings of the Carolingian history were "constructed." The ways in which the historical narrative was organized thus requires further investigation. One of the examples of pro-Carolingian propaganda that addressed the coming to power of Pippin III, the annals of Lorsch, attributed to the pope Zachary II the proposal to choose the mayor as 
the king because he was the one who at that moment wielded truly kingly power: "The pope [Zacharias] ordered the Frankish king and the Franks that they call Pippin, who de facto used the royal power, the king, and that they enthrone him. And this was done by the unction of saint Boniface in Soisson" (Annales Laurissenses Minores 1826, p. 751). ${ }^{1}$ This is an example of how historians in the Carolingian age sought to find sanction to the dynasty's rule by appealing to the prestige of papacy. But this kind of entry in the annals is most likely the later one because the earlier, more contemporary sources show much less interest to the event or even the problem of legitimacy itself. Only three sources address the coronation of Pippin III and they significantly differ in their accounts and in their assessment of papacy's role. Thus in the three sources, such as the Chronicle of the Contunuator Fredegarii, Annales regni francorum, and Clausula de unctione Pippini we see how the depiction changed depending on the time of the composition of the source and on the position of the annalist in regards to the coming of the new king. One may notice how only in the Lorsch annals, otherwise called as the Royal Frankish annals, the special sanction of the pope was emphasized and how the annalist portrayed the coronation as the symbol of Carolingians' special connection to the papacy and hence of their universal triumph (MCKITTERICK 2000b, p. 15-16, 21; MCKITTERICK 2004 , p. 136). I argue that the coronation of 751 had not been the only event in the Frankish history that became a matter of interpretation for historians in the vein of their own attitude to the Frankish kings and their relative standing within the complex networks of power. In the forthcoming investigation I seek to suggest that there were few more events, the historical representation of which was constructed by historians for the purpose of creating a consistent narrative of the history of the Carolingian Frankish kingdom.

Historical representations of the past in the early Carolingian age created a sense of continuous decay and anticipation of the coming of the new strongmen from among the mayors of the palace and their kin before new approaches

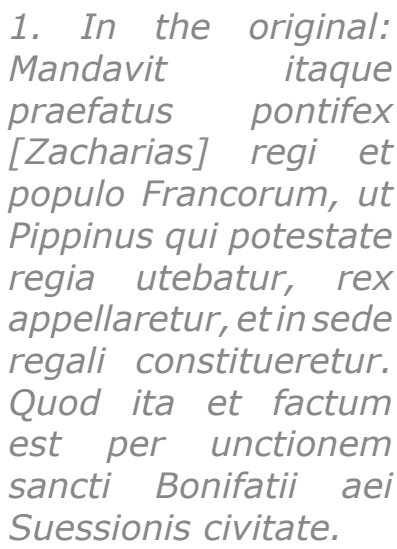

1. In the original: Mandavit itaque praefatus pontifex [Zacharias] regi et populo Francorum, ut Pippinus qui potestate regia utebatur, rex appellaretur, et in sede regali constitueretur. Quod ita et factum est per unctionem Suessionis civitate. 
to this period came about (LOT PFISTER; GANSHOF 1928, p. 280-296; SCHNEIDER 1995, p. 19-20; BOSHOF 1990, p. 161-190; REIMITZ 2014, p. 150). This postulate had not been questioned since Einhard's famous passage that claimed them to be ineffectual and losing importance, before scholars started paying attention to the internal stability of the late Merovingian kingdom. But a number of studies suggested that this claim of the weak kings was nothing more than a Carolingian construction since Merovingian historians saw their contemporary kings as legitimate and the kingdom as stable (GERBERDING 1992; FOURACRE; GERBERDING 1996). Thus despite several attempts at usurpation the Merovingian family was seen as the only force in the Frankish kingdom that possessed symbolic capital to represent authority (WOOD 2004, p. 15-16, 31). At the same time, on the other side of historiographical divide created by Einhard in the early Carolingian period, there have been made other observations of the new dynasty's inefficacious status that made their rule seem as problematic as that of the Merovingians. Thus the coming of the Carolingians to power has been recently seen as a much more complex process than it has been previously believed and no triumphal accession has been considered to have taken place because of the instability within the family of the mayors. Charles Martell might not have been viewed by his contemporaries as a successful mayor with a claim to almost kingly powers, the image which was ascribed to him by some modern scholars. In fact, he may have been for them nothing more than an heir to Pippin II (HEIDRICH 1989 , p. $220-226$; JOCH 1994 , p. 169 ; WOOD 2004, p. 15). Competition between relatives was so intense that it was until 754 that Pippin III was being considered as only a co-ruler to his brother Carloman and, after the later's demise, to his nephew Drogo (GOOSMANN 2015, p. 56).

Development of history as a discipline in the last one hundred years has led to a serious re-evaluation of knowledge of the past as a means of self-identification of communities. It has been suggested that societies, in order to stay cohesive, construe their image by relying on consensus in regards to 
the interpretation of their past (HALBWACHS 1925; BURKE 1969, p. 18-19; BLOCH 1992, p. 26; MCKITTERICK 2004, p. $85)$. It has been shown by a number of influential studies that all attempts to create a community's self-identification are in one way or another based on the interpretation of the past, which is to support the community-approved vision of history (FENTRESS; WICKHAM 1992, ch. 7). This memory, created for the self-identification of a community, is always legitimized and accepted socially by means of communication (MOSTERT 1999; MCKITTERICK 2004, p. 85). Thus it has been shown that in the Carolingian kingdom the image of authority and the message its officers were to translate to local magnates, aristocracy and general populace was created as a set of historical reminiscences, and not just as a confirmation of contemporary state of affairs by way of a panegyric. The reception of these reminiscences as the norm of community's self-identification took place by means of communication between the members of the community, both within the educated groups and outside. Multiplication of the number of chronicles and annals in the Carolingian age in comparison to the previous period supports the idea that many more people than ever before, even though they might have been of privileged, clerical status, were interested in perceiving and in turn producing the Carolingian version of the past and making it their own vision. The sheer number of annals support this idea. Development of history writing as a common occupation among monastic and clerical communities that took a dominant role in the written culture shows that the main way of assessing the rulers was to place them within historical context. Authors like Einhard, Nithard, Thegan, Astronomer, who showed the most of personal commentary on the history of the Frankish kingdom, sought to convey their vision of the contemporary Frankish events by means of historical treatises (MCKITTERICK 2004, p. 84-173; BARNWELL 2005, p. 139). In about the decade Charlemagne became for those who remembered him a symbol of the "Golden Age" and thus part of history instead of being just the recent past (GABRIELE 2011, p. 17). Even Einhard, who sought to describe the life of Charlemagne as if he was still his contemporary was writing 
his treatise at least a decade later and himself recognized that it required a great deal of delving into the past and that it already had little contemporaneity with the events he sought to describe as seminal for the expansion of Frankish authority over the whole Europe:

There are, I do not doubt, many men of learning and leisure who feel that the life of the present day must not be utterly neglected, and that the doings of our own time should not be devoted to silence and forgetfulness as wholly unworthy of record; who, therefore, have such love of fame that they would rather chronicle the great deeds of others in writings, however poor, than, by abstaining from writing, allow their name and reputation to perish from the memory of mankind. But, even so, I have felt that I ought not to hold my hand from the composition of this book, for I knew that no one could write of these events more truthfully than I could, since I was myself an actor in them, and, being present, knew them from the testimony of my own eyes; while I could not certainly know whether anyone else would write them or no. I thought it better, therefore, to join with others in committing this story to writing for the benefit of posterity rather than to allow the shades of oblivion to blot out the life of this King, the noblest and greatest of his age, and his famous deeds, which the men of later times will scarcely be able to imitate (EINHARD 1905, The prologue). ${ }^{2}$

It was claimed to be written in $830 \mathrm{~s}$, although some scholars claim it was produced no later than 823 (TISCHLER 2001, p. 78-239). This peculiarity of the Carolingian worldview, in which much discussion about the legitimacy of power was projected onto the past and was legitimized within this particular context, was emphasized by scholars recently. It was argued, for example, that almost all historical treatises were uniform in reflecting the voice of the elite (MCKITTERICK 2000a, p. 172174). It is important, however, to investigate deeper the ways in which historical narratives were constructed and used with the purpose of advancing agendas contemporary for their authors. It seems that further development of these topics is in order, and one may particularly look to investigate the balance between tropes common to historical narratives since Late Antiquity, the Carolingian worldview or, in the most radical terms, "propaganda," and the personal vision of the past by educated scholars.
2. In the original: Et quamquam plures esse non ambigam, qui otio ac litteris dediti statum aevi praesentis non arbitrentur ita neglegendum, ut omnia penitus quae nunc fiunt velut nulla memoria digna silentio atque oblivioni tradantur, potiusque velint amore diuturnitatis inlecti aliorum praeclara facta qualibuscumque scriptis inserere quam sui nominis famam posteritatis memoriae nihil scribendo subtrahere, tamen ab huiuscemodi scriptione

e $x$ is $i \mathrm{~m}$ a $v i$ t e $m p$ erandum, quando mihi conscius eram nullum ea veracius quam me scribere posse, quibus ipse interfui, quaeque praesens oculata, ut dicunt, fide cognovi et, utrum $a b$ alio scriberentur necne, liquido scire non potui. Satiusque iudicavi eadem cum aliis velut communiter litteris mandata memoriae posterorum tradere quam regis excellentissimi et omnium sua aetate maximi clarissimam vitam et egregios atque moderni temporis hominibus vix imitabiles actus pati oblivionis tenebris aboleri. 
The sense of continuous construction of history in a way that was beneficial to Charlemagne, his retainers and magnates or to the educated people, who sought to make up for the missing bits of the glorious past, appears immediately after one looks in the classical piece of written work no one has ever denied the right to be the source of information. Einhard has been believed to have produced a sort of a panegyric in his Vita Caroli Magni that can be taken at face value. In fact, scholars have posed no objection to taking this work as a pro-Carolingian propaganda. But even in the relatively homogenous narrative that was dedicated to one goal, to use Charlemagne's authority and success to prove his greatness to the readers in the age of Louis the Pious, we may find how even here the very distant past was reshaped or rejected by Einhard since it did not fit the main narrative of Charlemagne's peak years. It has been noted that in the 760s Pippin III's, Charlemagne's and Carloman's rule might have been seen by contemporaries as that which had still lacked the desired legitimacy or at least acceptance by everybody (GOOSMANN 2015, p. 56). It is a remarkable fact that Einhard disregarded the early years of Charlemagne by saying that there was no reliable information and that they could be easily overlooked. He emphasized that he would start his narrative with the physical description of the king and continue with his development as a person and a king. This was, to my judgment, another way of saying that the status of Charlemagne within the progeny of Charles Martell and Pippin III was something in which people just a generation later were uninterested. Charlemagne attracted the attention of Einhard and others only from the standpoint of later achievements and results of his reign. His early history had been lost on the next generation because it had little indication of his unique status he acquired by the end of his reign.

It would be foolish of me to say anything about his birth and infancy, or even about his boyhood, for I can find nothing about these matters in writing, nor does anyone survive who claims to have personal knowledge of them. I have decided, therefore, to pass on to describe and illustrate his acts and his habits and the other divisions of his life without lingering over the unknown. 
I shall describe first his exploits both at home and abroad, then his habits and interests, and lastly the administration of the kingdom and the end of his reign, omitting nothing that demands or deserves to be recorded (EINHARD, 1905, cap. 4). ${ }^{3}$

From among the events that caused the historian to disparage readers from turning to the early years of the Carolingian history one may name the implicit tensions between Charlemagne and Carloman upon their accession as kings in 768 (CLASSEN 1972, p. 124; MCKITTERICK 2008, p. 77-82; BACHRACH 2013, p. 110). The death of Carloman made the tensions surrounding the division of the kingdom so high that Charlemagne's cousin Adalhard, abbot Fulrad of St-Denis and count Warin precluded the former's wife Gerberga from taking over any kind of regent's position and invited Charlemagne to take over Carloman's part of the kingdom (Annales Mettenses Priores 1905, p. 771; EINHARD 1911, cap. 3; RICHÉ 1991, p. 86).

This situation was implicitly acknowledged by Einhard who recognized in the preface to his work that there were latent tensions plaguing the representations of the early history of the Carolingians. Thus he expressed certainty in the fact that many will consider the current events (and by this he meant the already distant story of Charlemagne's reign) worthy of description. This suggests that there were also those who thought the story of Charlemagne could be put aside. But moreover, hidden in his serendipitous locution was the theme of people who in their love for present-day events might deem writing about the past unnecessary. He, on the other hand, insisted on making the past needed, although Charlemagne had already been dead for at least a decade. This means that his treatise was openly constructed as an attempt to unearth the forgotten past and make it relevant, which implies a significant amount of reshaping this past (EINHARD 1911, Praefatio).

\section{The Divisions of the Kingdom and the Historian's Craft.}

Just as Einhard proposed to look over the earlier history of Charlemagne and presented instead a continuous narrative
3. In the original: De cuius nativitate atque infantia vel etiam pueritia quia neque scriptis usquam aliquid declaratum est, neque quisquam modo superesse invenitur, qui horum se dicat habere notitiam, scribere ineptum iudicans ad actus et mores ceterasque vitae illius partes explicandas ac demonstrandas, omissis incognitis, transire disposui; ita tamen, ut, primo res gestas et domi et foris, deinde mores et studia eius, tum de regni administratione et fine narrando, nihil de his quae cognitu vel digna vel necessaria sunt praetermittam. 
of the king's military campaigns, he also overlooked another important event that in many ways was critical for the development of Carolingian authority. Just as the problem of accommodating Charlemagne and Carloman from 768 to 771 caused a significant stir and a lasting trail of historical innuendo, in the same fashion the attempt to divide the empire in 806 by the document called Divisio regnorum left for contemporaries and historians a problem of interpreting it against the historical realities. The document was an important one since it possessed its own manuscript history and it was not included wholesale into collections of capitularies (TISCHLER 2008, p. 231). By this document Charlemagne ensured for his three sons three parts of the empire, while making them regni consortes instead of real kings. This document carefully provided for the rules of succession (MCKITTERICK 2008, p. 96-102). It might have been due to the fact that he himself was crowned a king and an emperor. The part of Charles the Younger included Neustria and Austrasia, and thus was unusually large as compared to the lots of other sons. This fact found no explanation in chronicles, while some modern scholars supposed that the king of the Franks specifically gave him a large and yet undefined territory to make him a co-ruler of sorts. Charlemagne saw him as his successor and perhaps, a ruler of his own while his father was living (CLASSEN 1972, p. 132). Others, however, saw nothing special in this decision (KASCHKE 2008, p. 275). They emphasized that this document provided no further prerogatives the sons might have been supposed to enjoy as the result of the division and hinted at no special functions they could exercise. Thus an obscure act by Charlemagne left historians wondering about its exact meaning for the Carolingian kingdom and empire.

This system of division needed a ruler who could supervise its implementation. Scholars have noticed that the Divisio regnorum was not approved in any kind of assembly, and thus from the formal standpoint was not a testament per se, but a document expressing the desirable path of events in the future (GIESE 2008, p. 455). Thus the emperor must have thought that one of his sons would acquire a position higher than the 
other two and would thus be able to look after the terms of Divisio regnorum. While Einhard provides no further clues about the situation, another historian, Thegan may provide a key to understanding the ways in which the division was to be put into practice (THEGANUS 1995, cap. 6).

Unlike Einhard or Astronomer, Thegan never served for historians as an exemplary case of pro-Carolingian propaganda. His stance on the family of Charlemagne was never straightforward and supportive because he paid significant attention to the conflict within it, and thus his work turned into one of the main sources for the events leading to the division of the kingdom at Verdun in 843. It is in this treatise that the last years of Charlemagne's rule are shown as those which represent the gradual decay of his authority and thus of the royal authority's viability. This is how Thegan's account differs from that of Einhard. It was this history that made twentieth-century scholars to speak about the general decline of Charlemagne's authority and the demise of his kingdom and the empire (GANSHOF 1948, p. 451).

Thegan's treatise produces an ambivalent picture because it both shows Charlemagne's and his son's predicament in transferring power from one to another and their success in doing so. Thus we learn that Louis the Pious' coronation was an event that brought him and his father Charlemagne closer together, and at the same time we see how the kingdom and the empire remained in the hands of Charlemagne as his son left for Aquitaine, the part provided for him as part of a division of the kingdom within the family. This was a significant moment because it showed how the coronation, in the eyes of Thegan, did not change anything in the power balance and in the representation of authority at the Frankish court. What did this ceremony of coronation imply if it did not immediately change the status of the son within the power structure of the kingdom?

Thegan casts the history of Charlemagne and Louis the Pious in terms of biblical discourse in the part which deals with 
the family situation and hierarchy within the family. Louis the Pious was the younger son of the king of the Franks and the emperor, but the situation within the family was such that one needs to look at the rules of succession closely. Looking at the family politics at the Carolingian court, scholars noted that the primogeniture, which was at least in theory the norm of succession among the Frankish kings, was in this case under serious pressure. The problem lay in Pippin the Hunchback who, as scholars thought, might have been excluded from succession because of his deformity despite being the elder son of Charlemagne (GOFFART 1986, p. 93). Renaming of Carloman as Pippin made scholars strengthen their belief in this turn of affairs. This assessment of the family matters produced an impression that at the court of Charlemagne there was a feeling directed towards sidelining the elder son in favor of the younger ones, the trend that effectively undermined the Frankish primogeniture rules. On the other hand, it has been suggested that no attempts at sidelining him actually took place and until his revolt in 792 his position within the family was strong (HAMMER 2008, p. 276). Thus until at least 792 one may not see in the Carolingian court any pressure on the elder sons (NELSON 2002, p. 283). But in Thegan's work one may notice a singular emphasis on the role of the younger son in contrast to that of the elder one. This meant that unlike Einhard, Thegan constructed the history of Charlemagne in a way that emphasized new topics and that re-wrote the earlier attempts of historians to find sense in the family relationships of Charlemagne's offspring.

Moreover, the ways in which Thegan represented the coming of Louis the Pious to power show how much invisible tension surrounded the Carolingian court, the Carolingians as the family and their relationship with local magnates. It was once proposed that the last years of Charlemagne's reign were a "decomposition" completely opposite to the "triumph" of the earlier years and of the victories over the Saxons and other "nations" of Europe (GANSHOF 1948, p. 451; GANSHOF 1971, p. 259). Scholars established a tradition of seeing Louis the 
Pious as a weak king who never managed to achieve the same authority and prestige as his father (STAUBACH 1990, p. 722). Thus the last years of Charlemagne's reign and the coronation of his successor are considered to be much more dramatic than it has been thought. Let us look at how this was portrayed in Thegan's chronicle. I argue that from the first lines one may sense in this treatise a tension between the normal, peaceful pace of events that the supporters of the dynasty might have wanted to see, and the alternative picture that exhibited tensions, problems and absence of uniform acceptance of the Carolingians' authority.

Thegan thus needs to be investigated as an example of the Carolingian dichotomy of authority's message and discordant voices. I would argue that his work is in many ways unique because of the span of the differences of interpretation in positive or negative way of the "Gesta's" narrative, which could allow interpreters, unlike in the cases of Einhard or Nithard, to produce totally opposite views of this historical period. On the one hand, the history of Thegan described in a very positive and assertive light how Charlemagne at the top of his career and life path made his younger son Louis the Pious an heir to his imperial title and a co-ruler:

The above-mentioned emperor, when he understood his last to be coming - since had become quite old -- called upon his son Louis to come to him, as well as invited all host, bishops, abbots, dukes, counts, his representatives. He held a general council with them in Aachen palace peacefully and honestly, and informed them that he puts his faith in his son, and then inquired all from the most important people to the least important ones, whether they would like if he transferred his title, that it, that of the emperor, to his son Louis (THEGANUS 1995, cap. 6). ${ }^{4}$

This passage evokes the image of the peaceful and/ or organized transfer of power, done with the consent of all powerful people in the kingdom of both lay and clerical status. One may note that Thegan implied the real transfer of power ("tradidisse") from Charlemagne to Louis, and not a co-rulership as one might have imagined. If this passage is

\begin{abstract}
4. In the original:
Supradictus vero

imperator,

iam

cum

adpropinquare

dies obitum suum senuerat enim valde

- vocavit filium suum

Hludouuicum ad se

cum omni exercitu,

episcopis, abbatibus,

ducibus, comitibus,

locopositus. Habuit

generale colloquium

cum eis Aquisgrani

palatio pacifice et

honeste, ammonens,

ut fidem erga filium

suum ostenderent,

interrogans omnes

a maximo usque

ad minimum, si

eis placuisset, ut

nomen suum, id

est imperatoris,

filio suo Hludounico tradidisset.
\end{abstract}


to be understood correctly and literally, it may mean that the historian implied Charlemagne's retirement from power from the moment of Loius' coronation. This is an ideal picture, or at least, it is the most literal reading of the passage.

It deserves to be noted that Thegan did not perceive a single shade of tragedy in the last years of Charlemagne even though the latter's two sons had passed away: Solus Hludouuicus ad regni gubernacula remansit (THEGANUS 1995, cap. 5). He sought to portray the succession in a peaceful and predetermined way as the action that was approved by all significant people in the kingdom. Further description of the succession produces even stronger impression of the universal acceptance because Thegan wrote how, upon everybody agreeing with the king's desire, Charlemagne immediately proceeded to organize the ceremony of Louis' coronation. But it is interesting that in this passage the initial presentation of the event as a transfer of power was significantly modified by the description of the ceremony which involved the second crown, due to be picked up by the incumbent king Louis. One may surmise that this crown signified not just the royal title which Louis had already acquired by virtue of his rulership in Aquitaine, but a desire of Charlemagne or Thegan to show the transmission of power as the process of establishing the coemperor.

They responded in joy, that this announcement was the one that pleased God. As it had been done, next Sunday [Charlemagne] decorated himself according to the royal cult and put on the crown, and went on his way beautifully decorated, as it was due to him. He went to the church, to which he himself had laid the foundation, went to the altar that was constructed in the place more eminent that other altars and that was consecrated in the honor of our Lord Jesus Christ; on which he put the golden crown, the different one from that he had on his head. After that he and his spoke, and in front of the multitude of bishops and optimates he told and informed his son, in the first place to honor and be afraid of the omnipotent God, to serve his commandments in total, to govern the God's churches and to defend them from bad men (THEGANUS 1995, cap. 5). ${ }^{5}$ 
Establishment of the co-rulership in this way is a particularly interesting and intriguing topic because the unity and divisions of power in the Carolingian kingdom were the two opposites which have been considered as highly problematic by modern historians (BOSHOF 1990, p. 161-163).

I suggest that Thegan's description of the ceremony by which Louis the Pious had become a crowned king and emperor in his own right is the piece of the puzzle that is missing from the Divisio regnorum's interpretation. The latter document did not provide all information about the actual division of power. It is likely at Charlemagne saw Charles the Younger as a sort of higher ruler above other sons. Once he was gone, Louis the Pious took over this role in the ceremony that was aimed at buttressing the position not only of the king, but also of the supreme ruler in the Empire, in the kingdom as an indivisible unit and the key person in the family. But only the historical narrative, and not the original documents, constructed this history in a way that made it understandable. The story of the coronation told by Thegan, which showed that Charlemagne had something in his pocket which he preferred not to show in the Divisio regnorum, was in some way a response to the uncertainties of the last years of Charlemagne's rule. This "secret" was a coronation, during which his son put upon himself his own crown and did so with his own hands, without intrusion of any other person. This kind of coronation relieved his son of the dependence on the Pope or any other bishop or monk, and thus established the new king as the true emperor of the indivisible Empire that was "independent" from any external influence. In a sense, the projected image of stability that this coronation produced was the construction of the historian (perhaps, reflecting the overall feeling of the magnates) and was to serve, in my opinion, as a compensation for the uncertainties that flourished both in the last years of Charlemagne and in the early years of Louis the Pious.

Apart from the coronation of 751 , the divisions of 768 and 806 were critical episodes in the history of the Carolingian kingdom. Interestingly, they both can only be understood 
through the work of the historians who constructed a narrative in a meaningful way, using dichotomies of older son and younger sons, the theme of the favorite son of the king, the episode of the single-handed individual coronation and so on. Much as with the coronation of 751, the historical picture of the coronation of Louis the Pious we use today was constructed by contemporary historians and it could not have been produced by relying only on documents. It was not a "fabrication" in the negative sense of the term, but a "construction" in the positive meaning. Thus key episodes of Charlemagne's reign could not be understood without the Carolingian historians' "authorial license". Only the historical narrative construed a meaningful sequence of events that could be reproduced in memory. But at the same time, once we approach these key events, we are left with historians' interpretations rather than facts. Thus the Carolingian period in the history of the Frankish kingdom, and particularly the reign of Charlemagne, can be seen as a constructed narrative, which cannot be perceived without looking at the context of its origin and the authors' "creative" influence on the representation of the past.

\section{REFERÊNCIAS BIBLIOGRÁFICAS}

AMMIANUS MARCELLINUS. Rerum gestarum libri qui supersunt. Ed. by W. Seyfarth. Stuttgart: Teubner, 1999.

Annales Laurissenses Minores. 1826. In: MGH SS. Vol. 1 , p. 112-123.

Annales Mettenses Priores. Hrsg. von B. Simson, MGH Scriptores rerum germanicarum in usum scholarum, Bd. 10. Hannover: Hahn, 1905.

AUBIN, H. Die Herkunft der Karlinger. In: Karl der Grosse oder Charlemagne? Acht Antworten deutscher Geschichtforscher. Berlin: E. S. Mittler, p. 44ff., 1935.

BACHRACH, B. Charlemagne's Early Campaigns (768- 
777): A Diplomatic and Military Analysis. History of Warfare 82. Boston: Brill, 2013.

BARNWELL, Paul S. Einhard, Louis the Pious and Childeric III. In: Historical Research 78:200, p. 129-139, 2005.

BLOCH, Marc. The Historian's Craft. Manchester: Manchester University Press, 1992.

BONNELL, Heinrich. Die Anfänge des Karolingischen Hauses. Berlin: Duncker und Humblot, 1866.

BOSHOF, Egon. Einheitsidee und Teilungsprinzip in der Regierungszeit Ludwigs des Frommen. In: Charlemagne's Heir: New Perspectives on the Reign of Louis the Pious (814-840). Ed. by Peter Godman and Roger Collins. Oxford: Clarendon Press, p. 161-90, 1990.

BRUNNER Heinrich, VON SCHWERIN Carl. Deutsche Rechtsgeschichte. $2^{\text {nd }}$ ed. Berlin, 1958.

BULLOUGH, D. Europae pater: Charlemagne and his Achievement in the Light of Recent Scholarship, In: English Historical Review, v. 85, p. 59-105, 1970.

BURKE, Peter. The Renaissance Sense of the Past. London: Edward Arnold, 1969.

CARDINI, Franco. Europe and Islam. Oxford: Blackwell, 2001.

CLASSEN, Peter. Karl der Grosse und der Thronfolge im Frankenreich. In: Festschrift für Hermann Heimpel. Veröffentlichungen des Max-Plank-Instituts für Geschichte 3. Göttingen, S. 109-134, 1972.

COSTAMBEYS, Marios, INNES, Matthew, MACLEAN, Simon. The Carolingian World, Cambridge Medieval Textbooks. Cambridge: Cambridge University Press, 2011.

Early Lives of Charlemagne by Eginhard and the Monk of 
St Gall. A. J. Grant, trans., London: Moring, 1905, p. 1-56.

EINHARD. The Life of Charlemagne. Tr. by S. E. Turner. New York: Harper and Brothers, 1880.

EINHARD, Vita Karoli Magni. Hrsg. von G. H. Pertz, Georg Waitz und Oswald Holder-Egger. MGH Scriptores rerum Germanicarum in usum scholarum separatim editi 25. Hannoverae: Impensis Bibliopolii Hahniani, 1911.

FENTRESS, J. and WICKHAM, Chris. Social Memory. Oxford: Blackwell, 1992.

FOURACRE, Paul and GERBERDING, Richard A. Late Merovingian France: History and Hagiography, 640-720. Manchester Medieval Sources. Manchester: Manchester University Press, 1996.

FRIED, Johannes. Karl der Grosse: Gewalt und Glaube. München: Beck, 2014.

FUSTEL DE COULANGES, Numa Denis. Histoire des institutions politiques de I'ancienne France, v. 7, Transformations de la royauté pendant l'epoque carolingienne. Paris: Librarie Hachette, 1907.

GABRIELE, Matthew. An Empire of Memory: the Legend of Charlemagne, the Franks, and Jerusalem before the First Crusade. Oxford; New York: Oxford University Press, 2011.

GANSHOF, François. L. Charlemagne's Failure. In: F. L. Ganshof, The Carolingians and the Frankish Monarchy. Ithaca, p. 256-59, 1971.

- La fin du règne de Charlemagne, une décomposition. In : Revue suisse d'histoire, p. 433-51, 1948.

GANZ, David. Einhard's Charlemagne: The Characterisation of Greatness. In: Charlemagne: Empire and Society. Ed. 
by Joanna Story. Manchester, p. 38-51, 2005. . The Astronomer's Life of Louis the Pious. In:

Rome and Religion in the Medieval World: Studies in Honor of Thomas F. X. Noble. Ed. by Valerie L. Garver and Owen M. Phelan. London: Routledge, p. 129-148, 2014.

GERBERDING, Richard. The rise of the Carolingians and the Liber historiae Francorum. Oxford: Clarendon Press, 1992.

GIESE, Wolfgang. Die designativen Nachfolgeregelungen der Karolinger 714-979. In: Deutsches Archiv für Erforschung des Mittelalters 64.2, S. 437- 512, 2008.

GOFFART, Walter. Paul the Deacon's 'Gesta Episcoporum Mettensium' and the Early Design of Charlemagne's Succession. In: Traditio 42, p. 59- 93, 1986.

GOOSMANN, Erik. Politics and Penance: Transformations in the Carolingian Perception of the Conversion of Carloman (747). In: The Resources of the Past in Early Medieval Europe. Ed. by Clemens Gantner, Rosamond McKitterick, and Sven Meeder. Cambridge: Cambridge University Press, p. 51-67, 2015.

HALBWACHS, M. Les cadres sociaux de la mémoire. T. 8. Bibliothèque de L'évolution de I'humanité 367. Paris: Albin Michel, 1925.

HAMMER, Carl I. 'Pipinus Rex': Pippin's Plot of 792 and Bavaria. In: Traditio 63, p. 235-76, 2008.

HEIDRICH, Ingrid. Les maires du palais neustriens du milieu du VIIe au milieu du VIIIe sècle. In: La Neustrie: Les pays au nord de la Loire de 650 à 850 . Sous la dir. de H. Atsma. T. 1. Beihefte der Francia 16. Sigmaringen, p. 217-229, 1989.

HLAWITSCHKA E., Die Vorfahren Karls des Grossen, In: Karl der Grosse: Lebenswerk und Nachleben. Ed. By 
Wolfgang Braunfels. Bd. 1. Düsseldorf, p. 51-82, 1966.

HLAWITSCHKA E. Zur landschaftlichen Herkunft der Karolinger, Rheinische Vierteljahrsblätter. Bd. 27, p. 1-17, 1962.

HODGES, R., WHITEHOUSE, D. Mohammed, Charlemagne, and the Origins of Europe: Archeology and the Pirenne Thesis. Ithaca, NY: Cornell University Press, 1983.

JOCH, W. Karl Martell - ein mindberechtiger Erbe Pippins. In: Karl Martell in seiner Zeit. Ed. by J. Jarnut, U. Nonn, and M. Richter. Beihefte der Francia 37. Sigmaringen, p. 149-169, 1994.

KASCHKE, Sören. Tradition und Adaptation. Die "Divisio regnorum" und die fränkische Herrschaftsnachfolge. In: Herrscher- und Fürstentestamente im westeuropäischen Mittelalter. Hrsg. von Brigitte Kasten. Norm und Struktur 29. Köln, S. 259-289, 2008.

LEVILLAIN, L. L'avenement de la dynastie carolingienne et les origines de l'etat pontifical 745-757, In: Bibliotheque de l'ecole des chartes. v. 94, p. 225-95, 1933.

LOT, F., C. PFISTER et F. L. GANSHOF. Histoire du Moyen Âge. T. 1 : Les destinees de I'Empire en Occident de 395 à 888. Paris : Presses Universitaires de France, 1928.

MCKITTERICK, Rosamond. Charlemagne: the Formation of a European Identity. Cambridge: Cambridge University Press, 2008.

History and Memory in the Carolingian

World. Cambridge: Cambridge University Press, 2004.

Political Ideology in Carolingian Historiography. In: The Uses of the Past in the Early Middle Ages. Ed. by Yitzhak Hen and Matthew Innes. 
Cambridge, p. 162-174, 2000a.

. The Illusion of Royal Power in the Carolingian Annals. In: English Historical Review 115:460, p. 1-20, 2000b.

MORALES, Ambrosio de, OCAMPO, Florián de. La coronica general de España. En Alcala de Henares: En casa de Iuan Iñiguez de Lequeríca, 1574.

MOSTERT, Marco, ed. New Approaches to Medieval Communication. Utrech Studies in Medieval Literacy. Turnhout, 1999.

NELSON, Janet L. Charlemagne: pater optimus? In: Am Vorabend der Kaiserkrönung: das Epos "Karolus Magnus et Leo papa" und der Papstbesuch in Paderborn 799. Hrsg. von P. Godman, J. Jarnut und P. Johanek. Berlin: Akademie Verlag, S. 271-283, 2002.

Public Histories and Private History in the Work of Nithard. In: Speculum 60.2, p. 251-293, 1985.

PIRENNE H. Mahomet et Chalemagne. Paris: Alcan, 1937.

REIMITZ, Helmut. Viri inlustres und omnes Franci: Zur Gestaltung der feinen Unterschiede in historiographischen und diplomatischen Quellen der frühen Karolingerzeit. In: Urkunden - Schriften - Lebensordnungen. Neue Beiträge zur Mediävistik. Hrsg. von Andreas Schwarcz und Katharina Kaska. Veröffentlichungen des Instituts für Österreichische Geschichtsforschung 63. Wien, S. 123-150, 2014.

RICHÉ, Pierre. The Carolingians: A Family who Forged Europe. Philadelphia: University of Pennsylvania Press, 1991.

Le renouveau culturel a la cour de Pepin III, In: Francia, Bd. 2, p. 59-70, 1974. 
SCHNEIDER, Reinhard. Das Frankenreich. 3. Aufl. Oldenbourg Grundriss der Geschichte 5. München: Oldenbourg, 1995.

SCHUTZ, Herbert. The Carolingians in Central Europe, their History, Arts, and Architecture: a Cultural History of Central Europe, 750-900. Leiden; Boston: Brill, 2004.

STAUBACH, N. 'Des grossen Kaisers kleiner Sohn': Zum Bild Ludwigs der Frommen in der älteren deutschen Geschichtsforschung. In: Charlemagne's Heir: New Pespectives on the Reign of Louis the Pious. Ed. by Peter Godman and Roger Collins. Oxford, p. 701-22, 1990.

THEGANUS. Gesta Hludowici imperatoris. Bd. 64. MGH SRG. Hannover: Hahnsche Buchhandlung, 1995.

TISCHLER, Matthias M. Die "Divisio regnorum" von 806 zwischen handschriftlicher Überlieferung und historiographischer Rezeption. In: Herrscher- und Fürstentestamente im westeuropäischen Mittelalter. Hrsg. von Brigitte Kasten. Norm und Struktur 29. Köln, S. 193- 2582008.

. Einharts "Vita Karoli": Studien zur Entstehung, Uberlieferung und Rezeption. Bd. 1. Schriften der Monumenta Germaniae Historica 48. Hannover: Hahnsche, 2001.

WATSON, William E. The Battle of Tours-Poitiers Revisited, In: Providence: Studies in Western Civilization. v. 2(1), p. $51-68,1993$.

WEINFÜFTER, Stefan. Karl der Grosse: Der heilige Barbar. München: Piper, 2015.

WHITE L. Medieval Technology and Social Change. Oxford: Clarendon Press, 1962.

WOOD, I. N. Usurpers and Merovingian kingship. In: 
Der Dynastiewechsel von 751. Vorgeschichte, Legitimationsstrategien und Erinnerung. Ed. by $M$. Becher and S. Dick. Münster: Scriptorium, p. 15-31, 2004. . Misremembering the Burgundians. In: Suche nach den Ursprüngen: von der Bedeutung des frühen Mittelalters, Denkschriften, Österreichische Akademie der Wissenschaften, Philosophisch-historische Klasse, Bd. 322. Ed. by Walter Pohl. Forschungen zur Geschichte des Mittelalters 8. Wien: Verlag der Oesterreichischen Akademie der Wissenschaften, p. 139-148, 2004.

\section{AGRADECIMENTOS E INFORMAÇŌES}

\section{Dmitri Starostin}

starostin.dmitry@gmail.com

d.starostin@spbu.ru

Assistant Professor, The Institute of History

University of St-Petersburg

Mendeleevskaia linia, 5

Saint-Petersburg 199034

Russian Federation 